\title{
Is There a Relation between Changes in Osmolarity of Cherry Fruit Flesh or Skin and Fruit Cracking Susceptibility?
}

\author{
Annick Moing1, Christel Renaud, Hélène Christmann, Lydie Fouilhaux, Yves Tauzin, and \\ Anne Zanetto \\ Unitéde Recherches sur les Espèces Fruitières et la Vigne, Institut National de la Recherche Agronomique, \\ Centre de Bordeaux, BP 81, F-33883 Villenave d'Ornon, cedex, France \\ Monique Gaudillère \\ UMR Physiologie et Biotechnologie Végétales, Institut National de la Recherche Agronomique, Centre \\ de Bordeaux, BP 81, F-33883 Villenave d'Ornon, cedex, France

\begin{abstract}
Frédéric Laigret and Jacques Claverie
Unitéde Recherches sur les Espèces Fruitières et la Vigne, Institut National de la Recherche Agronomique, Centre de Bordeaux, BP 81, F-33883 Villenave d'Ornon, cedex, France
\end{abstract}

AdDitional INDEX words. fruit cracking, fruit quality, organic acids, osmotic potential, Prunus avium, soluble sugars

\begin{abstract}
Rain-induced fruit cracking is a limiting factor for sweet cherry (Prunus avium L.) growers in many production areas. Although many studies have concerned this complex phenomenon, the basic mechanisms involved in fruit cracking remain unclear. We re-examined the relations between osmotic potential and cracking susceptibility in cherry fruit by comparing the osmotic contribution of the major metabolites separately in flesh and skin, in four cultivars (with different levels of susceptibility to cracking) at four stages of development. Several differences were observed between flesh and skin revealing compositional gradients in the fruit tissues. Acidity and malate concentrations were higher in flesh than in skin for all stages. The absolute value of osmotic potential was higher but the contribution of the sum of sugars to osmotic potential was lower in flesh than in skin. As determined using fruit immersion test, 'Fermina' and 'Regina' were less susceptible to fruit cracking than 'Lapins' and 'Brooks'. At commercial maturity when fruit susceptibility to cracking was highest, no clear difference appeared between 'Brooks' and 'Lapins' compared to 'Regina' and 'Fermina' for flesh or skin osmolarity and for the contribution of the major sugars or organic acids to skin and flesh osmotic potential.
\end{abstract}

Fruit cracking and splitting is a serious economic problem in several crops, including tomato, apple, pear, citrus, pomegranate, grape, and cherry (Opara et al., 1997). For sweet cherry growers in many production areas, rain-induced fruit cracking is a limiting factor. In spite of many studies, the basic mechanisms involved in the complex phenomenon of fruit cracking remain unclear. The physiological and cytological mechanisms involved include fruit water budget, fruit morphology, and fruit tissue structure (cuticle, cell walls, cell sizes) (Christensen, 1996; Opara et al., 1997; Sekse, 1998). These mechanisms are complex and often interrelated.

Concerning fruit water budget, osmotic potential of the cherry fruit has been considered to be a critical factor of cracking mechanisms in the past (Sekse, 1995, 1998). Osmotic potential is a component of the fruit water potential that is the driving force for water uptake. Data on the osmotic and turgor components of the cherry fruit water potential are rare (Andersen and Richardson, 1982). Cherry fruit water potential varies greatly (-900 to $-2500 \mathrm{kPa}$ ) during the harvest period depending on the cultivar

Received for publication 19 Dec. 2003. Accepted for publication 8 Feb. 2004. We thank the 'Unité Expérimentale Arboricole du Centre INRA de Bordeaux' for taking care of the trees, P. Angiuli for help during preliminary experiments, N. Ollat and M. Génard for critical reading of the manuscript, B. Ricard for correcting the English, and anonymous reviewers for helping us to improve the manuscript. ${ }^{1}$ Corresponding author. Present address: UMR Physiologie et Biotechnologie Végétales, Institut National de la Recherche Agronomique, Centre de Bordeaux, BP 81, F-33883 Villenave d'Ornon, cedex, France. e-mail: moing@bordeaux.inra.fr and diurnal measurement time (Tvergyak and Richardson, 1979). However, at a given water supply, osmotic potential determines the fruit turgor, which can be related to skin failure (Considine and Kriedemann, 1972). Cherry fruit cracking has been related to increased internal turgor resulting from absorption of water into the fruit (Christensen, 1996; Sekse, 1998). The water uptake threshold at which fruit cracked was a major factor explaining differences in cracking resistance among some cultivars (Lane et al., 2000).

The major organic contributors to osmotic pressure in cherry flesh at maturity are glucose and fructose (4\% to $9 \%$ fresh weight) and malate (0.5\% to $0.9 \%$ fresh weight) (Girard and Kopp, 1998). Verner (1937) described a sugar concentration gradient from the base to the apex of the fruit, which could be related to cracking areas. Later studies (Christensen, 1972a) found little correlation between refractometer reading and cracking index.

Varietal differences for cracking susceptibility are considerable (Christensen, 2000; Roser, 1996). Therefore, the development of high-quality crack-resistant cultivars remains a major objective in several breeding programs. The selection criteria still involve observation for several years in the orchard and fruit immersion tests such as the one developed by Christensen (1972b). The correlation between orchard and in vitro tests is not perfect. Sensitivity to fruit cracking also depends on the stage of development of the fruit. Severe cracking is not observed until the third growth phase (Christensen, 1973a). Sensitivity to cracking increases as the fruit ripens and decreases in some cultivars after normal harvest time (Christensen, 1973b). These changes 
in susceptibility to cracking must be taken into account for the development of selection criteria.

The objectives of the present study were to re-examine the relations between osmotic potential and cracking susceptibility in cherry fruit by comparing the osmotic contribution of the major metabolites separately in flesh and skin. Since water uptake into the fruit occurs from the other parts of the tree through the pedicel and also over the fruit surface (Sekse, 1998), we hypothesized that osmotic potential of the skin might be more related to in vitro cracking susceptibility than osmotic potential of the flesh. We worked on four cultivars, with different levels of susceptibility to cracking, at four stages of development.

\section{Materials and Methods}

Plant material. Fruits were harvested at the 'Unité Expérimentale Arboricole' (Toulenne near Langon, France) during May and June 2002 from four sweet cherry cultivars: 'Brooks', 'Lapins', 'Regina', and 'Fermina'. 'Brooks', obtained in California (Hansche et al., 1988), and 'Lapins', obtained in Canada (Lane and Schmid, 1984), have fruit with good firmness, and sweet taste but are susceptible to rain-induced fruit cracking. However, 'Lapins' is less susceptible to cracking (Lane et al., 2000; Ystaas and Froynes, 1998) than 'Brooks' (Hansche et al., 1988). 'Regina', obtained in Germany is appreciated in northern countries due to its delayed maturity date and resistance to fruit cracking (Roser, 1996; Y staas and Froynes, 1998). 'Fermina' (for which an application for Plant Breeder's right has been submitted to the European Community Plant Variety Office), obtained at INRA France in 1991, has large fruits and is more resistant to fruit cracking than 'Lapins' (J. Claverie, unpublished data from orchard observation and immersion tests). The cultivars were grafted on 'SL 64' rootstock and the trees were 7 to 11 years old. Cultural practices and pest control were the usual for cherry. Fruit samples were harvested at four development stages: green ( $\approx 1$ week before pink stage), pink (one-fourth to one-third of the fruit surface covered with pink color), commercial and physiological maturity (determined by color using a CR-200 Minolta chromameter). For each stage and genotype, fruits were harvested in the morning. Twenty fruits were harvested for determination of individual fruit fresh weight and juice collection, and 25 other fruits for determination of fruit cracking index.

DETERMINATION OF CRACKING INDEX. Fruit cracking index was determined after immersion in distilled water of 25 fruits for each genotype and development stage and observation of cracked fruits (Christensen, 1972b).

Juice Measurements. After determination of fruit weight, the fruit were grouped into five samples of four fruit each. For each fruit sample, the flesh (mesocarp) was separated from the skin [epidermis and hypodermal layers (Tukey and Oran Young, 1939) for a total thickness of $1 \mathrm{~mm} \pm 0.2]$ using a 3.5-cm surgical blade. Cross-contamination of skin and flesh was limited by working fast. Flesh and skin samples were immediately frozen in liquid $\mathrm{N}$ in a $10-\mathrm{mL}$ syringe containing a small paper filter at the needle and then stored at $-20{ }^{\circ} \mathrm{C}$ until analysis. After thawing for $20 \mathrm{~min}$ at $4^{\circ} \mathrm{C}$, the juice was extracted by hand pressing, centrifuged at $3800 g_{\mathrm{n}}$ at $4{ }^{\circ} \mathrm{C}$ and the resulting supernatent was stored in ice before analysis within $1 \mathrm{~h}$. The acidity of the juice supernatent was determined by measuring the $\mathrm{pH}$ of a $150-\mu \mathrm{L}$ sample using a pH meter (Schott Geräte, Germany) equipped with a microelectrode. Titratable acidity was determined by titration of a $100-\mu \mathrm{L}$ sample of juice (diluted 1:5 by volume with distilled water) with $0.1 \mathrm{~mol} \cdot \mathrm{L}^{-1} \mathrm{NaOH}$ to a $\mathrm{pH}$ of 8.3 . The osmotic potential of the juice supernatent was determined on 50 $\mu \mathrm{L}$ with a microosmometer (Roebling, Germany). Two hundred microliters of the juice supernatent was used for determination of soluble sugar and organic acid concentrations.

DETERMINATION OF SUGARS AND ORGANIC ACIDS. Two hundred microliters of juice was fixed with ethanol at $80{ }^{\circ} \mathrm{C}$ as described previously (Moing et al., 1997). Extracts were dried under vacuum, dissolved in pure water, and used for analysis of soluble sugars and organic acids. After purification of the neutral fraction, soluble sugars were analyzed by anion-exchange high-performance liquid chromatography (HPLC) with amperometry detection (CarboPac PA1 column; Dionex Corp., Sunnyvale, Calif.), as described previously (Moing et al., 1997), for some samples to identify major and minor soluble sugars in a preliminary experiment. Then, all samples were analyzed using HPLC with isocratic conditions and refractometry detection (Moing et al., 1998a). Organic acids were analyzed without sample purification, using anion-exchange HPLC with conductivity detection (Moing et al., 1998a, 1998b). Malic, quinic, citric, and isocitric acids were quantified. The total organic acids is the sum of these acids.

Sugars and organic acids were quantified with Millenium software from Waters (Milford, Mass.). HPLC peaks were identified by co-chromatography with commercial standards, their areas were calculated, and calibration was carried out with known quantities of sugar, and organic acid from Sigma (St Quentin Fallavier, France). Sugar and organic acid concentrations were used to calculate their contribution to juice osmolarity according to the Van't Hoff relation.

Statistical anAlysis. For fruit and biochemical variables, tissues were compared using variance analysis and mean separation with Student $t$ test. Genotypes were compared using variance analysis and mean separation with Tukey's test. Pearson correlation coefficient was calculated between cracking index and mean skin or flesh osmolarity for each stage and cultivar.

\section{Results}

Fruit deVElopment AND CRACKING INDEX. Full bloom ranged from 24 Mar. for 'Lapins', 25 Mar. for 'Brooks', 27 Mar. for 'Fermina', to 4 Apr. for 'Regina'. The fruit development stages were controlled using measurements of color $\mathrm{L} a \mathrm{~b}$ parameters (data not shown). The green stage date ranged from $52 \mathrm{~d}$ after tree full bloom (DAB) for 'Brook', 55 DAB for 'Fermina', 56 DAB for 'Regina', to 61 DAB for 'Lapins'. Commercial maturity date ranged from 30 May (66 DAB) for 'Brooks', 4 June (69 $\mathrm{DAB})$ for 'Fermina', 10 June (78 DAB) for 'Lapins', to 12 June (69 DAB) for 'Regina'. At commercial maturity, 'Regina' had a significantly lower fruit weight compared to the other cultivars (Fig. 1). 'Regina' and 'Fermina' fruit size continued to increase between commercial and physiological maturity ( $t$ test, $P<0.05$ ). At physiological maturity (6 d after commercial maturity), all the cultivars had a fresh weight higher than $8.6 \mathrm{~g}$ and 'Fermina' had a significantly highest fruit fresh weight in comparison to the other cultivars.

The highest fruit cracking index after immersion (Fig. 2) was observed for 'Brooks' at maturity stages. Moreover, 'Brooks' was the only cultivar where cracking of some fruits was observed at the green stage. 'Regina' and 'Fermina' had a cracking index lower than 20 at commercial maturity. 'Lapins' cracking indexes were intermediary between that of 'Brooks' and 'Regina' at maturity stages. For 'Brooks', 'Lapins', and 'Fermina', the highest cracking 


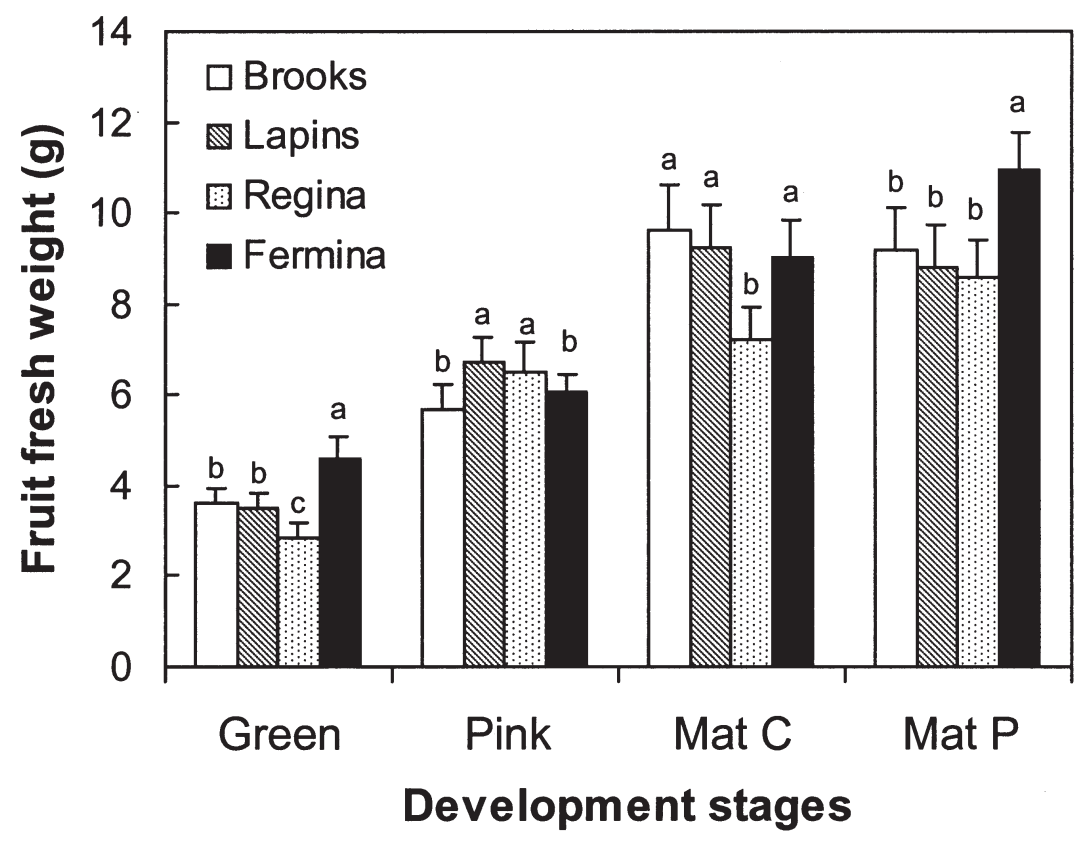

Fig. 1. Changes in fruit fresh weight during fruit development of 'Brooks', 'Lapins', 'Regina' and 'Fermina' cultivars. Mean of five samples. Vertical bars represent standard deviation. For each development stage, letters indicate mean separation among cultivars according to Tukey's test, $P<0.05$. Mat C, commercial maturity; Mat $\mathrm{P}$, physiological maturity.

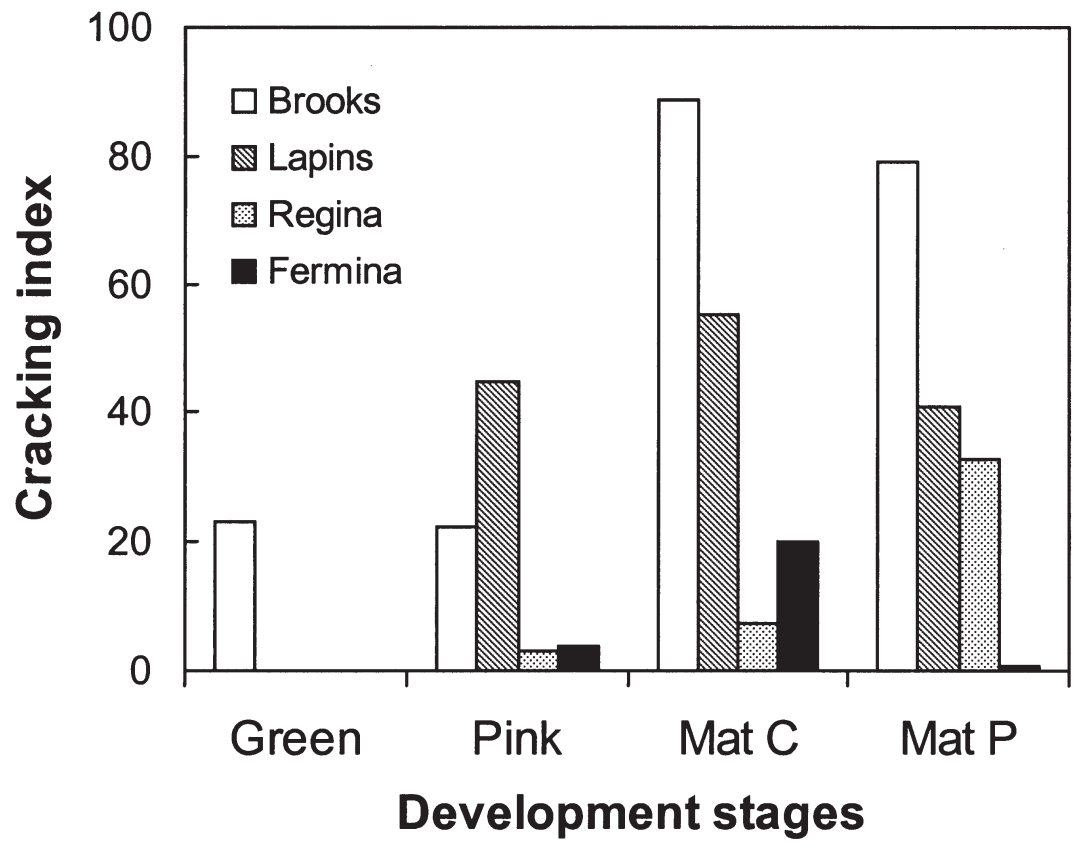

Fig. 2. Changes in cracking index during fruit development of 'Brooks', 'Lapins', 'Regina', and 'Fermina' cultivars. Cracking index was calculated using immersion of 25 fruits. Mat C, commercial maturity; Mat P, physiological maturity.

index was observed at commercial maturity. For 'Regina' significant cracking was observed only at physiological maturity.

JuiCE CHARACTERISTICS. A significant difference between skin and flesh (variance analysis not shown) was detected for juice $\mathrm{pH}$ and titratable acidity at all stages (Fig 3, mean acidity was significantly higher and mean $\mathrm{pH}$ was significantly lower in flesh compared to skin), and for juice osmotic potential at maturity stages (Fig 4, mean osmotic potential was significantly lower in flesh than in skin). The juice titratable acidity in flesh (Fig 3A) was significantly higher in 'Fermina' than in other cultivars for all stages. The juice titratable acidity in skin (Fig 3B) was significantly higher in 'Fermina' than in other cultivars for maturity stages.

The juice osmotic potential in flesh (Fig 4A) decreased between green and pink stages, and thereafter changes with time depended on the cultivar. Little significant differences were observed among cultivars except at pink stage when 'Brooks' had a flesh osmotic potential significantly higher than the other cultivars. The juice osmotic potential in skin (Fig 4B) decreased between green and commercial maturity stages and then remained stable at physiological maturity. Little significant differences were observed among cultivars except at pink stage when 'Brooks' and 'Fermina' had a skin osmotic potential significantly higher than the two other cultivars. For each stage, the cultivar pattern for osmotic potential was similar in flesh and skin except for commercial maturity stage.

For all stages and cultivars considered together, no significant correlation was observed between cracking index and osmolarity in skin $(R=0.40)$ or flesh $(R=0.37)(\mathrm{n}=16$, data not shown).

Carbohydrates. For all genotypes and stages, a preliminary experiment (data not shown) indicated that the major soluble sugars in flesh or skin juice were glucose and fructose (96 to $140 \mathrm{~g} \cdot \mathrm{L}^{-1}$ each), together representing $84 \%$ to $87 \%$ of total soluble sugars. Sorbitol represented $\approx 9 \%$ of total soluble sugars in flesh or skin juice at pink and green stages, and $12 \%$ to $15 \%$ at maturity stages. Sucrose represented $<0.5 \%$ of total soluble sugars. Xylose, inositol, rhamnose, and arabinose were also detected, each at a concentration lower than $0.4 \mathrm{~g} \cdot \mathrm{L}^{-1}$. Mannitol was not detected. The data presented below are derived from the isocratic-refractometric HPLC system where the minor sugars are not detected (only inositol is detected but not separated from fructose) since the sum of sorbitol, glucose, and fructose represented $\approx 99 \%$ of total soluble sugars in the preliminary experiment. The mean total soluble carbohydrate concentration (glucose, fructose, sorbitol, and inositol) ranged from 82 to $189 \mathrm{~g} \cdot \mathrm{L}^{-1}$ in flesh, and 84 to $174 \mathrm{~g} \cdot \mathrm{L}^{-1}$ in skin, depending on the stage and cultivar.

ORGANIC ACIDS. The major organic acid in flesh and skin was malate, representing more than $89 \%$ of the sum of organic acids. For all stages and cultivars, mean concentrations in flesh ranged between 5.2 and $10.7 \mathrm{~g} \cdot \mathrm{L}^{-1}$ for malate, 0.19 and $0.54 \mathrm{~g} \cdot \mathrm{L}^{-1}$ for quinate, 0.04 and $0.23 \mathrm{~g} \cdot \mathrm{L}^{-1}$ for citrate, and 0.01 to $0.05 \mathrm{~g} \cdot \mathrm{L}^{-1}$ for isocitrate. Mean concentrations in skin ranged between 3.2 and $6.4 \mathrm{~g} \cdot \mathrm{L}^{-1}$ for malate, 0.21 and $0.42 \mathrm{~g} \cdot \mathrm{L}^{-1}$ for quinate, 0.04 and $0.16 \mathrm{~g} \cdot \mathrm{L}^{-1}$ for citrate, and 0.01 to $0.04 \mathrm{~g} \cdot \mathrm{L}^{-1}$ for isocitrate. For each cultivar and stage, malate concentration was significantly higher in flesh compared to skin (paired $t$ test $P<0.05$ ).

OSMOTIC CONTRIBUTIONS OF CARBOHYDRATES AND ORGANIC ACIDS. In flesh (Table 1), the mean contribution of the sum of sugars to osmotic potential ranged from $55 \%$ to $79 \%$, and that of the sum of organic acids from $4 \%$ to $8 \%$. In skin (Table 2), the mean contribution of the sum of sugars to osmotic potential ranged from $61 \%$ to $84 \%$, and that of the sum of organic acids 

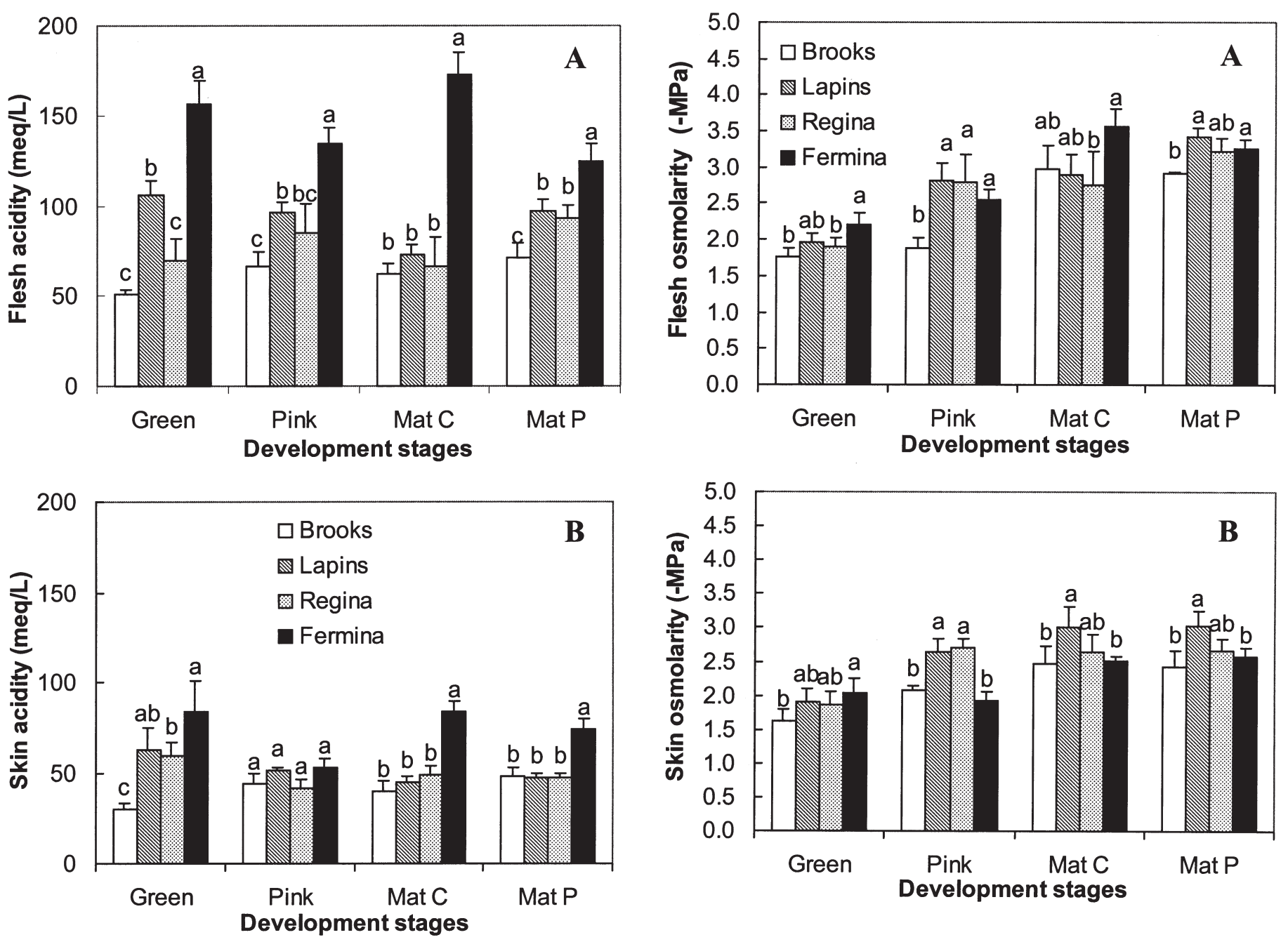

Fig. 3. Changes in juice $\mathrm{pH}(\mathbf{A})$ and titratable acidity (B) in flesh and skin during fruit development of 'Brooks', 'Lapins', 'Regina', and 'Fermina' cultivars. Mean of five samples. Vertical bars represent standard deviation. For each development stage, letters indicate mean separation among cultivars according to Tukey's test, $P<0.05$. Mat C, commercial maturity; Mat $\mathrm{P}$, physiological maturity.

from $2 \%$ to $6 \%$. The contribution of the sum of sugars increased and that of organic acids decreased in skin and flesh from green stage to physiological maturity.

The contribution of each sugar followed a distinct pattern. In flesh (Table 1), glucose was the major contributor $(29 \%$ to $37 \%$ of osmotic potential) with little or no change in different cultivars and stages. Fructose contribution increased from green $(22 \%$ to $26 \%$ ) to pink stage ( $25 \%$ to $30 \%$ ) and then remained stable. Sorbitol contribution increased from pink stage (3\% to 6\%) to physiological maturity (9\% to $10 \%$ ). Similarly, in skin (Table 2), glucose was the major contributor (35\% to $45 \%$ of osmotic potential) with little or no change with cultivars and stages. Fructose contribution increased from green (19\% to $22 \%$ ) to pink stage (27\% to $30 \%)$ and then remained stable. Sorbitol contribution increased from pink stage (3\% to $6 \%$ ) to physiological maturity (10\% to $13 \%)$. However, the glucose to fructose ratio was higher in skin (1.2:2.1) compared to flesh (1.1:1.5).

The contribution of malate to osmotic potential followed that of the sum of organic acids. Malate contribution decreased from green stage to physiological maturiry in flesh (Table $1,5 \%$ to $8 \%$ to $4 \%$ to $5 \%$ ) and in skin (Table $2,4 \%$ to $6 \%$ to $2 \%$ to $4 \%$ ).

Fig. 4. Changes in osmotic potential in flesh (A) and in skin (B) during fruit development of 'Brooks', 'Lapins', 'Regina', and 'Fermina' cultivars. Mean of five samples. Vertical bars represent standard deviation. For each development stage, letters indicate mean separation among cultivars according to Tukey's test, $P<0.05$. Mat C, commercial maturity; Mat $\mathrm{P}$, physiological maturity.

However, malate contribution was higher in flesh than in skin. Little significant differences among cultivars were observed for the contribution of the major sugars and organic acids to flesh or skin osmotic potential (Tables 1 and 2).

\section{Discussion}

CONSISTENCY WITH PREVIOUS STUdIES OF BIOCHEMICAL FRUIT COMPOSITION IN CHERRY. The percentages and the concentrations of the major soluble sugars observed in all cultivars were in general agreement with published data (Girard and Kopp, 1998; Neubeller and Stösser, 1977). The glucose and fructose concentrations and their ratio were similar but sorbitol concentration was lower in the present experiment than the "mannitol+sorbitol" concentration published by Girard and Kopp (1998). Moreover, mannitol was not detected in our experiment. Among the minor sugars detected, rhamnose, arabinose, and xylose present as cell wall bound sugars in pericarp (Kondo and Danjo, 2001) may indicate cell wall turnover.

The concentrations of malate and citrate were in agreement with previous data (Girard and Kopp, 1998; Looney et al., 1996). 
Table 1. Osmotic potential (data from Fig. 4A) and calculated percentage of the osmotic potential contributed by glucose, fructose, the sum of soluble sugars (sum SS), malate, the sum of organic acids (sum OA) in juice collected from flesh of 'Brooks', 'Lapins', 'Regina', and 'Fermina' fruit at four different stages.

\begin{tabular}{|c|c|c|c|c|c|c|c|c|}
\hline \multirow[b]{2}{*}{ Genotype } & \multirow[b]{2}{*}{ Stage } & \multirow{2}{*}{$\begin{array}{c}\text { Osmotic potential } \\
(\mathrm{MPa})\end{array}$} & \multicolumn{6}{|c|}{ Contribution to osmotic potential (\%) } \\
\hline & & & Glucose & Fructose & Sorbitol & Sum SS & Malate & Sum OA \\
\hline Brooks & Green & $-1.77 \mathrm{~b}^{\mathrm{z}}$ & $36.9 \mathrm{a}$ & $25.5 \mathrm{a}$ & $3.4 \mathrm{c}$ & $66.1 \mathrm{a}$ & $5.4 \mathrm{c}$ & $5.7 \mathrm{c}$ \\
\hline Lapins & & $-1.96 \mathrm{ab}$ & $32.6 \mathrm{~b}$ & $21.5 \mathrm{~b}$ & $6.2 \mathrm{a}$ & $60.4 \mathrm{~b}$ & $7.6 \mathrm{a}$ & $8.1 \mathrm{a}$ \\
\hline Regina & & $-1.91 \mathrm{~b}$ & $31.4 \mathrm{bc}$ & $22.2 \mathrm{~b}$ & $4.1 \mathrm{~b}$ & $57.9 \mathrm{bc}$ & $6.6 \mathrm{~b}$ & $7.0 \mathrm{~b}$ \\
\hline Fermina & & $-2.20 \mathrm{a}$ & $29.1 \mathrm{c}$ & $22.1 \mathrm{~b}$ & $3.2 \mathrm{c}$ & $54.6 \mathrm{c}$ & $8.1 \mathrm{a}$ & $8.3 \mathrm{a}$ \\
\hline Brooks & Pink & $-1.88 \mathrm{~b}$ & $35.1 \mathrm{a}$ & $29.5 \mathrm{ab}$ & $4.6 \mathrm{~b}$ & $69.3 \mathrm{a}$ & $5.2 \mathrm{~b}$ & $5.4 \mathrm{~b}$ \\
\hline Lapins & & $-2.82 \mathrm{a}$ & $33.2 \mathrm{a}$ & $29.2 \mathrm{ab}$ & $6.6 \mathrm{a}$ & $69.3 \mathrm{a}$ & $4.7 \mathrm{~b}$ & $4.9 \mathrm{~b}$ \\
\hline Regina & & $-2.79 \mathrm{a}$ & $34.5 \mathrm{a}$ & $30.3 \mathrm{a}$ & $6.5 \mathrm{a}$ & $71.5 \mathrm{a}$ & $5.1 \mathrm{~b}$ & $5.3 \mathrm{~b}$ \\
\hline Fermina & & $-2.55 \mathrm{a}$ & $28.4 \mathrm{~b}$ & $25.2 \mathrm{~b}$ & $4.6 \mathrm{~b}$ & $58.9 \mathrm{~b}$ & $6.2 \mathrm{a}$ & $6.4 \mathrm{a}$ \\
\hline Brooks & Commercial & $-2.98 \mathrm{ab}$ & $35.7 \mathrm{a}$ & $32.2 \mathrm{a}$ & $7.3 \mathrm{ab}$ & $75.3 \mathrm{a}$ & $3.7 \mathrm{~b}$ & $3.8 \mathrm{~b}$ \\
\hline Lapins & Maturity & $-2.90 \mathrm{ab}$ & $32.3 \mathrm{~b}$ & $29.2 \mathrm{~b}$ & $8.0 \mathrm{a}$ & $69.5 \mathrm{ab}$ & $3.8 \mathrm{~b}$ & $4.0 \mathrm{~b}$ \\
\hline Regina & & $-2.74 b$ & $33.1 \mathrm{ab}$ & $29.5 \mathrm{~b}$ & $6.6 \mathrm{~b}$ & $69.2 \mathrm{ab}$ & $3.9 \mathrm{~b}$ & $4.0 \mathrm{~b}$ \\
\hline Fermina & & $-3.56 \mathrm{a}$ & $31.8 \mathrm{~b}$ & $30.0 \mathrm{ab}$ & $6.4 \mathrm{~b}$ & $68.4 \mathrm{~b}$ & $5.5 \mathrm{a}$ & $5.5 \mathrm{a}$ \\
\hline$\overline{\text { Brooks }}$ & Physiological & $-2.91 b$ & $37.0 \mathrm{a}$ & $33.1 \mathrm{a}$ & $8.6 \mathrm{ab}$ & $78.8 \mathrm{a}$ & $3.8 \mathrm{~b}$ & $3.9 \mathrm{~b}$ \\
\hline Lapins & Maturity & $-3.42 \mathrm{a}$ & $34.5 \mathrm{ab}$ & $30.5 \mathrm{bc}$ & $9.6 \mathrm{a}$ & $74.7 \mathrm{ab}$ & $3.8 \mathrm{~b}$ & $4.0 \mathrm{~b}$ \\
\hline Regina & & $-3.21 \mathrm{ab}$ & $33.2 \mathrm{~b}$ & $28.5 \mathrm{c}$ & $10.0 \mathrm{a}$ & $71.7 \mathrm{~b}$ & $3.9 \mathrm{~b}$ & $4.0 \mathrm{~b}$ \\
\hline Fermina & & $-3.25 \mathrm{a}$ & $33.7 \mathrm{~b}$ & $31.6 \mathrm{ab}$ & $7.4 \mathrm{~b}$ & $72.8 \mathrm{ab}$ & $5.0 \mathrm{a}$ & $5.1 \mathrm{a}$ \\
\hline
\end{tabular}

zMean of five samples. Mean separation within stage according to Tukey's test, $P<0.05$.

Table 2. Osmotic potential (data from Fig. 4B) and calculated percentage of the osmotic potential contributed by glucose, fructose, the sum of soluble sugars (sum SS), malate, the sum of organic acids (sum OA) in juice collected from skin of 'Brooks', 'Lapins', 'Regina', and 'Fermina' fruit at four different stages.

\begin{tabular}{|c|c|c|c|c|c|c|c|c|}
\hline \multirow[b]{2}{*}{ Genotype } & \multirow[b]{2}{*}{ Stage } & \multirow{2}{*}{$\begin{array}{c}\text { Osmotic potential } \\
(\mathrm{MPa})\end{array}$} & \multicolumn{6}{|c|}{ Contribution to osmotic potential (\%) } \\
\hline & & & Glucose & Fructose & Sorbitol & Sum SS & Malate & Sum OA \\
\hline$\overline{\text { Brooks }}$ & Green & $-1.63 b^{z}$ & $44.5 \mathrm{a}$ & $21.8 \mathrm{a}$ & $3.1 \mathrm{c}$ & $69.4 \mathrm{a}$ & $4.1 \mathrm{c}$ & $4.4 \mathrm{~b}$ \\
\hline Lapins & & $-1.90 \mathrm{ab}$ & $38.4 \mathrm{~b}$ & $18.6 \mathrm{~b}$ & $6.1 \mathrm{a}$ & $63.2 \mathrm{ab}$ & $4.7 \mathrm{bc}$ & $5.1 \mathrm{ab}$ \\
\hline Regina & & $-1.85 \mathrm{ab}$ & $38.2 \mathrm{~b}$ & $18.7 \mathrm{~b}$ & $3.7 \mathrm{~b}$ & $60.8 \mathrm{~b}$ & $4.9 \mathrm{~b}$ & $5.3 \mathrm{a}$ \\
\hline Fermina & & $-2.03 \mathrm{a}$ & $37.9 \mathrm{~b}$ & $20.2 \mathrm{ab}$ & $3.9 \mathrm{~b}$ & $62.1 \mathrm{~b}$ & $5.7 \mathrm{a}$ & $5.9 \mathrm{a}$ \\
\hline$\overline{\text { Brooks }}$ & Pink & $-2.07 \mathrm{~b}$ & $40.5 \mathrm{a}$ & $27.6 \mathrm{~b}$ & $4.7 \mathrm{c}$ & $72.9 \mathrm{bc}$ & $3.6 \mathrm{~b}$ & $3.8 \mathrm{~b}$ \\
\hline Lapins & & $-2.64 \mathrm{a}$ & $38.8 \mathrm{ab}$ & $30.1 \mathrm{a}$ & $9.2 \mathrm{a}$ & $78.3 \mathrm{a}$ & $3.0 \mathrm{c}$ & $3.2 \mathrm{c}$ \\
\hline Regina & & $-2.70 \mathrm{a}$ & $36.0 \mathrm{c}$ & $26.8 \mathrm{~b}$ & $7.0 \mathrm{~b}$ & $69.9 \mathrm{c}$ & $3.1 \mathrm{c}$ & $3.3 \mathrm{c}$ \\
\hline Fermina & & $-1.93 b$ & $37.9 \mathrm{~b}$ & $29.7 \mathrm{a}$ & $7.2 \mathrm{~b}$ & $74.9 \mathrm{~b}$ & $4.4 \mathrm{a}$ & $4.6 \mathrm{a}$ \\
\hline$\overline{\text { Brooks }}$ & Commercial & $-2.46 b$ & $38.1 \mathrm{a}$ & $29.7 \mathrm{a}$ & $8.7 \mathrm{~b}$ & $76.7 \mathrm{a}$ & $2.7 \mathrm{~b}$ & $2.8 \mathrm{~b}$ \\
\hline Lapins & Maturity & $-3.02 \mathrm{a}$ & $35.2 \mathrm{a}$ & $28.5 \mathrm{a}$ & $10.5 \mathrm{a}$ & $74.2 \mathrm{a}$ & $2.3 \mathrm{c}$ & $2.4 \mathrm{c}$ \\
\hline Regina & & $-2.63 \mathrm{ab}$ & $37.3 \mathrm{a}$ & $28.8 \mathrm{a}$ & $8.2 \mathrm{~b}$ & $74.4 \mathrm{a}$ & $3.0 \mathrm{~b}$ & $3.2 \mathrm{~b}$ \\
\hline Fermina & & $-2.51 b$ & $35.2 \mathrm{a}$ & $29.9 \mathrm{a}$ & $8.6 \mathrm{~b}$ & $73.8 \mathrm{a}$ & $4.2 \mathrm{a}$ & $4.3 \mathrm{a}$ \\
\hline Brooks & Physiological & $-2.43 b$ & $41.1 \mathrm{a}$ & $32.4 \mathrm{a}$ & $10.1 \mathrm{~b}$ & $83.7 \mathrm{a}$ & $2.8 \mathrm{~b}$ & $3.0 \mathrm{~b}$ \\
\hline Lapins & Maturity & $-3.03 \mathrm{a}$ & $37.1 \mathrm{~b}$ & $27.8 \mathrm{c}$ & $12.6 \mathrm{a}$ & $77.5 \mathrm{~b}$ & $1.9 \mathrm{~d}$ & $2.1 \mathrm{~d}$ \\
\hline Regina & & $-2.67 \mathrm{ab}$ & $39.0 \mathrm{ab}$ & $28.0 \mathrm{bc}$ & $12.9 \mathrm{a}$ & $80.0 \mathrm{ab}$ & $2.4 \mathrm{c}$ & $2.5 \mathrm{c}$ \\
\hline Fermina & & $-2.57 b$ & $35.5 \mathrm{~b}$ & $30.3 \mathrm{ab}$ & $9.6 \mathrm{~b}$ & $75.4 \mathrm{~b}$ & $3.9 \mathrm{a}$ & $4.0 \mathrm{a}$ \\
\hline
\end{tabular}

zMean of five samples. Mean separation within stage according to Tukey's test, $P<0.05$.

Ascorbic acid could not be quantified in our experiment due to degradation during extraction and separation. The concentration of quinic acid was higher and that of citric acid was lower than in Oen and Vestrheim (1985).

Differences AMONG STAGES. According to the immersion test, the highest susceptibility to cracking was observed at commercial maturity for 'Brooks', 'Lapins', and 'Fermina', considered to be very susceptible, moderately susceptible, and resistant to cracking, respectively (Hansche et al., 1988; Lane and Schmid, 1984; Roser, 1996). Between green stage and commercial maturity, fruit size approximately doubled and osmotic potential increased by $\approx 30 \%$ in skin and $40 \%$ in flesh. As emphasized previously (Looney et al., 1996), the pattern of cherry fruit sizing is characterized by an accumulation of $\approx 25 \%$ of final fruit weight during the last week before harvest, with steady softening during the month preceding harvest. The mean fruit fresh weight was stable between commercial and physiological maturity for 'Brooks' and 'Lapins', but increased for 'Regina' and 'Fermina'. It may be interesting to verify if this late increase in fruit fresh weight, resulting mainly from cell enlargement, is accompanied by a late cessation of cell divisions in exocarp as shown for some other cultivars with low susceptibility to cracking (Yamaguchi et al., 2003).

DiffERENCES BETWEen FLESH AND SKIN. Several differences were observed between flesh and skin revealing compositional gradients in the fruit tissues. Acidity and malate concentrations were higher in flesh than in skin for all stages and cultivars. The 
tissue specificity of malic acid concentration has already been demonstrated in grape berries (Gutiérrez-Granda and Morrison, 1992) and may result from compartmentation of metabolism (Famiani et al., 2000).

The absolute value of osmotic potential was higher in cherry flesh than in skin, contrary to data obtained in pear cactus fruit (Nobel et al., 1994). The contribution of the sum of sugars to osmotic potential was lower in flesh than in skin. The glucose : fructose ratio was higher in skin than in flesh.

For facility purposes, skin was determined as the outer part of the fruit with a $1-\mathrm{mm} \pm 0.2$ thickness. We did not verify if the thickness of epidermal and hypodermal cell layers differed between stages and cultivars. However, the same biochemical differences between flesh and skin were observed for all cultivars and stages. Due to the respective fresh weight of skin and flesh, the contamination of flesh by juice issued from the skin should be negligible. Possible contamination of the skin by some juice coming from the flesh cannot be excluded. However, as we observed lower osmotic pressure and lower acidity in skin, this possible contamination must be low.

RELATIONSHIPS BETWEEN OSMOTIC POTENTIAL AND FRUIT CRACKING. The absolute value of osmotic potential in flesh or skin of mature cherry fruit ranged between 2.4 and $3.6 \mathrm{MPa}$ in the present study. The flesh values are in good agreement with those measured on fruit sap of 'Napoleon' cultivar (Andersen and Richardson, 1982). The cracking indexes observed in 'Brooks', 'Lapins', and 'Regina' were in general agreement with published data (Hansche et al., 1988; Lane et al., 2000; Roser, 1996; Ystaas and Froynes, 1998). 'Fermina' was less susceptible to fruit cracking, as determined using fruit immersion test (Christensen, 1972b), than 'Lapins'. At commercial maturity when fruit susceptibility to cracking after immersion was highest, no clear difference appeared between 'Brooks' and 'Lapins' compared to 'Regina' and 'Fermina' for flesh or skin osmotic potential and for contribution of the major sugar or organic acids to skin and flesh osmotic potential. Osmotic potential of the skin did not appear to be more related to in vitro cracking susceptibility than osmotic potential of the flesh. Therefore, global osmotic potentials of skin and flesh are not controlling factors for fruit cracking. However, the osmotic potential measured in skin or flesh results from osmotic potential in intracellular and intercellular (apoplast) spaces. Osmotic potential of intercellular spaces in skin may be important for water uptake through the fruit surface (Christensen, 1972a; Sekse, 1998). Differences among cultivars for susceptibility to cracking may result from a combination of changes in inner fruit composition as studied in the present experiment, epidermal cell plasticity (Yamaguchi et al., 2002), pedicel/fruit junction permeability to water (Beyer et al., 2002), and fruit surface characteristics, such as cuticle conductance to water (Beyer and Knoche, 2002; Knoche et al., 2000, 2001; Peschel et al., 2003) as investigated recently.

In conclusion, several differences were observed between flesh and skin revealing compositional gradients in the cherry fruit tissues. No clear difference appeared between the two susceptible compared to the two resistant cultivars for flesh or skin osmotic potential and for the contribution of the major sugar or organic acids to skin and flesh osmotic potential. Osmotic potential of the skin was not related to in vitro cracking susceptibility. These data confirm the complexity of the physiological mechanisms underlying susceptibility to cracking.

\section{Literature Cited}

Andersen, P.C. and D.G. Richardson. 1982. A rapid method to estimate fruit water status with special reference to rain cracking of sweet cherries. J. Amer. Soc. Hort. Sci. 107:441-444.

Beyer, M. and M. Knoche. 2002. Studies on water transport through the sweet cherry fruit surface: V. Conductance for water uptake. J. Amer. Soc. Hort. Sci. 127:325-332.

Beyer, M., S. Peschel, M. Knoche, and M. Knorgen. 2002. Studies on water transport through the sweet cherry fruit surface: IV. Regions of preferential uptake. HortScience 37:637-641.

Christensen, J.V. 1972a. Cracking in cherries. IV. Physiological studies of the mechanisms of cracking. Acta Agr. Scand. 22:153-162.

Christensen, J.V. 1972b. Cracking in cherries. III. Determination of cracking susceptibility. Acta Agr. Scand. 22:128-136.

Christensen, J.V. 1973a. Cracking in cherries. VI. Cracking susceptibility in relation to the growth rhythm of the fruit. Acta Agr. Scand. 23:52-54.

Christensen, J.V. 1973b. Cracking of sweet cherry. Erwerbsobstbau 15:123-125.

Christensen, J.V. 1996. Rain-induced cracking of sweet cherries: Its causes and prevention, p. 297-327. In: A.D. Webster and N.E. Looney (eds.). Cherries. Crop physiology, production and use. CAB Intl., Wallingford, U.K.

Christensen, J.V. 2000. Performance in Denmark of 16 European varieties of sweet cherry. J. Amer. Pomol. Soc. 54:172-176.

Considine, J.A. and P.E. Kriedemann. 1972. Fruit splitting in grapes: Determination of the critical turgor pressure. Aust. J. Agr. Sci. 23:17-24.

Famiani, F., R.P. Walker, L. Tecsi, Z.H. Chen, P. Proietti, and R.C. Leegood. 2000. An immunohistochemical study of the compartmentation of metabolism during the development of grape (Vitis vinifera $\mathrm{L}$.) berries. J. Expt. Bot. 51:675-683.

Girard, B. and T.G. Kopp. 1998. Physicochemical characteristics of selected sweet cherry cultivars. J. Agr. Food Chem. 46:471-476.

Gutiérrez-Granda, M. and J. Morrison. 1992. Solute distribution and malic enzyme activity in developing grape berries. Amer. J. Enol. Vitic. 43:323-328.

Hansche, P.E., W. Beres, J. Doyle, and W.C. Micke. 1988. 'Brooks' sweet cherry. HortScience 23:644.

Knoche, M., S. Peschel, M. Hinz, and M.J. Bukovac. 2000. Studies on water transport through the sweet cherry fruit surface: Characterizing conductance of the cuticular membrane using pericarp segments. Planta 212:127-135.

Knoche, M., S. Peschel, M. Hinz, and M.J. Bukovac. 2001. Studies on water transport through the sweet cherry fruit surface: II. Conductance of the cuticle in relation to fruit development. Planta 213:927-936.

Kondo, S. and C. Danjo. 2001. Cell wall polysaccharide metabolism during fruit development in sweet cherry 'Satohnishiki' as affected by gibberellic acid. J. Jpn. Soc. Hort. Sci. 70:178-184.

Lane, W.D., M. Meheriuk, and D.L. Mckenzie. 2000. Fruit cracking of a susceptible, an intermediate, and a resistant sweet cherry cultivar. HortScience 35:239-242.

Lane, W.D. and H. Schmid. 1984. Lapins and Sunburst sweet cherry. Can. J. Plant Sci. 64:211-214.

Looney, N.E., A.D. Webster, and E.M. Kupferman 1996. Harvest and handling sweet cherries for the fresh market. In: A.D. Webster and N.E. Looney (eds.). Cherries. Crop physiology, production and uses. CAB Intl., Wallingford, U.K.

Moing, A., F. Carbonne, B. Zipperlin, L. Svanella, and J.P. Gaudillere. 1997. Phloem loading in peach: Symplastic or apoplastic? Physiol. Plant. 101:489-496.

Moing, A., L. Svanella, D. Rolin, M. Gaudillere, J.P. Gaudillere, and R. Monet. 1998a. Compositional changes during the fruit development of two peach cultivars differing in juice acidity. J. Amer. Soc. Hort. Sci. 123:770-775.

Moing, A., L. Svanella, C. Rothan, D. Just, D. Rolin, R. Monet, P. Diakou, 
and J.P. Gaudillere. 1998b. Organic acid metabolism during the fruit development of two peach cultivars. Acta Hort. 465:425-432.

Neubeller, J. and R. Stösser. 1977. Sugar pattern in sweet cherries in the various parts of the fruit and in different years of investigation. Gartenbauwissenschaft 42:222-225.

Nobel, P.S., A.J.L.N. Wang, and G.B. North. 1994. Water potentials for developing cladodes and fruits of a succulent plant, including xylem-versus-phloem implications for water movement. J. Expt. Bot. 281:1801-1807.

Oen, H. and S. Vestrheim. 1985. Detection of non-volatile acids in sweet cherry fruits. Acta Agr. Scand. 35:145-152.

Opara, L.U., C.J. Studam, and N.H. Banks. 1997. Fruit skin splitting and cracking. Hort. Rev. 19:217-262.

Peschel, S., M. Beyer, and M. Knoche. 2003. Surface characteristics of sweet cherry fruit: Stomata-number, distribution, functionality and surface wetting. Sci. Hort. Amsterdam 97:265-278.

Roser, I. 1996. Investigations on cracking susceptibility of sweet cherry cultivars. Acta Hort. 331-337.

Sekse, L. 1995. Fruit cracking in sweet cherries (Prunus avium L.). Some physiological aspects-A mini review. Scientia Hort. 63:135-141.
Sekse, L. 1998. Fruit cracking mechanisms in sweet cherries (Prunus avium L.)-A review. Acta Hort. 637-648.

Tukey, H.B. and J. Oran Young. 1939. Histological study of the developing fruit of the sour cherry. Bot. Gaz. 100:723-749.

Tvergyak, P.J. and D.G. Richardson. 1979. Diurnal changes of leaf and fruit water potentials of sweet cherries during the harvest period. HortScience 14:520-521.

Verner, L. 1937. Reduction of cracking in sweet cherries following the use of calcium sprays. Proc. Amer. Soc. Hort. Sci. 36:271-274.

Yamaguchi, M., I. Sato, and M. Ishiguro. 2002. Influences of epidermal cell sizes and flesh firmness on cracking susceptibility in sweet cherry (Prunus avium L.) cultivars and selections. J. Jpn. Soc. Hort. Sci. 71:738-746.

Yamaguchi, M., I. Sato, A. Watanabe, and M. Ishiguro. 2003. Cultivar differences in exocarp cell growth pattern at apex, equator, stalk cavity and suture during fruit development in sweet cherry (Prunus avium L.). J. Jpn. Soc. Hort. Sci. 72:465-472.

Ystaas, J. and O. Froynes. 1998. Evaluation of sweet cherry cultivars and advanced selections adapted to northern climate. Acta Hort. 468:115-122. 